\title{
ARCHITECTURE OF SOKO WOLU TRADITIONAL HOUSE IN DUSUN CEMOROSEWU - MAGETAN
}

\author{
Johan Wahyudi ${ }^{1}$, Respati Wikantiyoso ${ }^{2}$ dan Junianto ${ }^{2}$ \\ ${ }^{1}$ Magister Architecture Postgraduate Program Student, Merdeka University Malang, \\ Jl. Terusan Raya Dieng No. 59, Malang, Indonesia \\ ${ }^{2}$ Lecturer of the Master of Architecture Study Program, Merdeka University Malang, \\ Jl. Terusan Raya Dieng No. 59, Malang, Indonesia \\ E-mail: johanwahyudi_arsitektur93a@yahoo.com
}

\begin{abstract}
Keywords:

Traditional house, omah soko wolu, Cemorosewu

Traditional houses in Indonesia have become silent witnesses of how life in the past was carried out and its influence on the order of life of the people at that time. Likewise with the traditional Javanese houses of the community of dusun Cemorosewu - Magetan, which have the characteristics and functionally have specific aims and objectives that influence the process of establishing the building. This study is expected to provide a benefit in the form of the development of knowledge related to traditional houses in general which can be applied in building architecture. The method used in this writing is descriptive method with non random sampling technique, which is purposive sampling (purposive sampling technique). From the discussion, it can be seen that the traditional house in dusun Cemorosewu only has two clusters, namely griya wingking with dhapur limasan and griya pawon with dhapur kampong where griya pawon is always on the left either the wingking house faces north or south. The supporting structure of the roof of the house is supported by 8 (eight) poles so that it is often referred to as omah soko wolu. Walls are made of split stone and zinc roofing and there are still cooking stoves that use fuel from firewood along with complementary components such as pogo and sigiran and roof openings in an effort to remove smoke.
\end{abstract}

Kata kunci:

Rumah

tradisional, omah

soko wolu, cemorosewu

\section{ABSTRAK}

Rumah-rumah tradisional di Indonesia telah menjadi saksi bisu tentang bagaimana kehidupan di masa lalu dijalankan dan pengaruhnya pada tatanan kehidupan masyarakat pada waktu itu. Demikian juga dengan rumah tradisional Jawa dari komunitas dusun Cemorosewu - Magetan, yang memiliki karakteristik dan secara fungsional memiliki tujuan tertentu yang mempengaruhi proses pendirian bangunan. Penelitian ini diharapkan dapat memberikan manfaat berupa pengembangan pengetahuan yang berkaitan dengan rumahrumah tradisional pada umumnya yang dapat diterapkan dalam membangun arsitektur. Metode yang digunakan dalam penulisan ini adalah metode deskriptif dengan teknik non random sampling, yaitu purposive sampling. Dari diskusi, dapat dilihat bahwa rumah adat di dusun Cemorosewu hanya memiliki dua kelompok, yaitu griya wingking dengan dapur limasan dan griya pawon dengan dapur kampong, di mana griya pawon selalu di sebelah kiri, rumah wingking menghadap ke utara atau selatan. Struktur pendukung atap rumah didukung oleh 8 (delapan) kutub, sehingga sering disebut sebagai omah soko wolu. Dinding terbuat dari batu split dan atap seng dan masih ada kompor masak yang menggunakan bahan bakar dari kayu bakar bersama dengan komponen pelengkap seperti pogo dan sigiran dan bukaan atap untuk menghilangkan asap.

@ 2017 The Authors. Published by GKAK UNMER Malang

*Corresponding Author: johanwahyudi_arsitektur93a@yahoo.com 


\section{INTRODUCTION}

The inheritance of many traditional Javanese architectural objects varies from Banten and Sunda in West Java, the Kilen Coast in Central and East Java, the Wetan Coast in East Java, Banyumas, Bagelen, Negarigung, Mancanegari, Surabaya, Tanah Sabrang Wetan and Madura. The architecture of the traditional house of Soko Wolu is part of traditional Javanese architecture where relics in the form of traditional architectural objects still exist. It is necessary that the objects of traditional house architecture of Soko Wolu located at dusun Cemorosewu - Magetan are further explored.

This research is the development of previous research that has been done by other researchers by taking almost the same objects but with different locations, namely: Karakteristik Rumah Tinggal Tradisional di Daerah Pegunungan Jawa Tengah (Hermawan, 2014) and Arsitektur Rumah Jawa Perdesaan pada Komunitas Hindu-Jawa di Kawasan Candi Cetho Gunung Lawu (Ikhsan, 2016). From the research it is known that there are several types of traditional residential houses in mountainous areas, namely houses that live in stone walls, with bamboo walls (gribik) and wood walls and are made based on traditional principles, namely the use of good dates and offerings in the procession. Traditional residences are handed down to their grandchildren and are rarely sold to other owners. The floor type of the house is mostly still from the ground or plaster, while the roof there are several kinds of variations both zinc, tile and other materials such as asbestos. In general, the Javanese house in dusun Cetho consists of two clusters, namely griya wingking and griya gandhok (pawon). The griya wingking group has various uses for the game, namely to receive guests, rest and sometimes as a bed. With the principle of facing east abstinence, the house generally faces north and south, where the griya pawon is always to the left of the griya wingking, even though the houses have different directions.

Based on the explanation above, the problem that will be studied is how traditional house architecture is in dusun Cemorosewu - Magetan. This study is expected to provide a benefit in the form of the development of knowledge related to traditional houses in general which can be applied in building architecture.

\section{STUDY OF LITERATURE}

\subsection{Traditional Living Room Structure}

Traditional residential houses in Java usually consist of

... a certain arrangement so that there are open pages and open wards, the space is rather open or closed. In determining where the building is considered in addition to use, it also has to do with nature such as the sun, direction of angina, direction of rain, underground water flow, and so on. Every attack on nature causes a wound that disturbs the balance. The task of the brother, which can also be called geoman, is the restoration or restoration of the balance. Because every object is directly related to other objects, it makes sense that any change at any given point requires a series of events in the microcosmic world that must be reconciled inside the wall surrounding the traditional residence. ${ }^{1}$

Surjadi Santoso. Zur Problematik des baulich-raumlichen Transformations prozesses in der vorkolonialen Epoche Javas / Indonesiens. Diss. unpublished. Hannover, 1981. p. 310. 


\section{Architecture of Soko Wolu Traditional House in Dusun Cemorosewu - Magetan}

Johan Wahyudi, Respati Wikantiyoso, dan Junianto

The wall surrounding the traditional house symbolizes the boundaries between the outside and the inside and allows the integration of natural elements into the human environment.

Traditional houses in Java in general are expressions of the nature of appreciation for life. Orientation to the cosmic axis from the north-south direction of the Ratu Kidul, the South Sea goddess and the protective goddess of the Kingdom of Mataram. Orientation to the cosmic axis from west-east to ordinary people is impossible because the east direction is used as an element of the palace. The east direction is also the residence of the god Yamadipati, who in the wayang story has the task of taking the lives of people. The basis for traditional residential planning takes into account the guidelines in terms of the main cosmic axis as shown in the following figure.

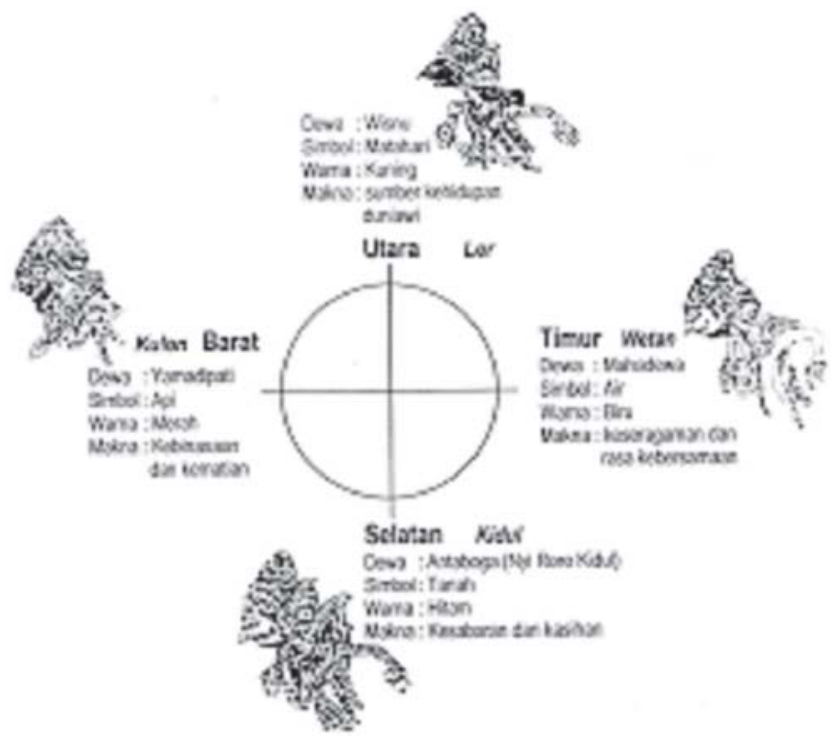

Figure 1 Guidance picture with the cosmic axis

(Source: Heinz Frick, 1997:85)

A traditional housing as a closed courtyard house in its structure is divided into two, namely the main house and additional houses. The main house consists of the following parts, pendopo, dalem agung, sentong, peringgitan and tratag. Whereas additional houses located beside and behind the main house consist of the following houses, gandok, gadri, pawon and pekiwan.

According to Frick (1997), based on the owner's position in the hierarchy and wealth, the housing complex is recommended to be adjusted, to be larger or smaller. The smallest form is the reduction of the great royal house. In the sense that traditional housing complexes play an anthropomorphic pattern $^{2}$ as an expression related to the art of buildings that are coupled on the north south axis. According to the anthropomorphic pattern, pendopo and peringgitan are commensurate with the head, dalem agung and gandok are commensurate with the body with the understanding of gandok as arm. Gadri, pawon and pekiwan are worth the feet. This is as shown in the following figure.

Anthropomorphs are shaped like humans. 


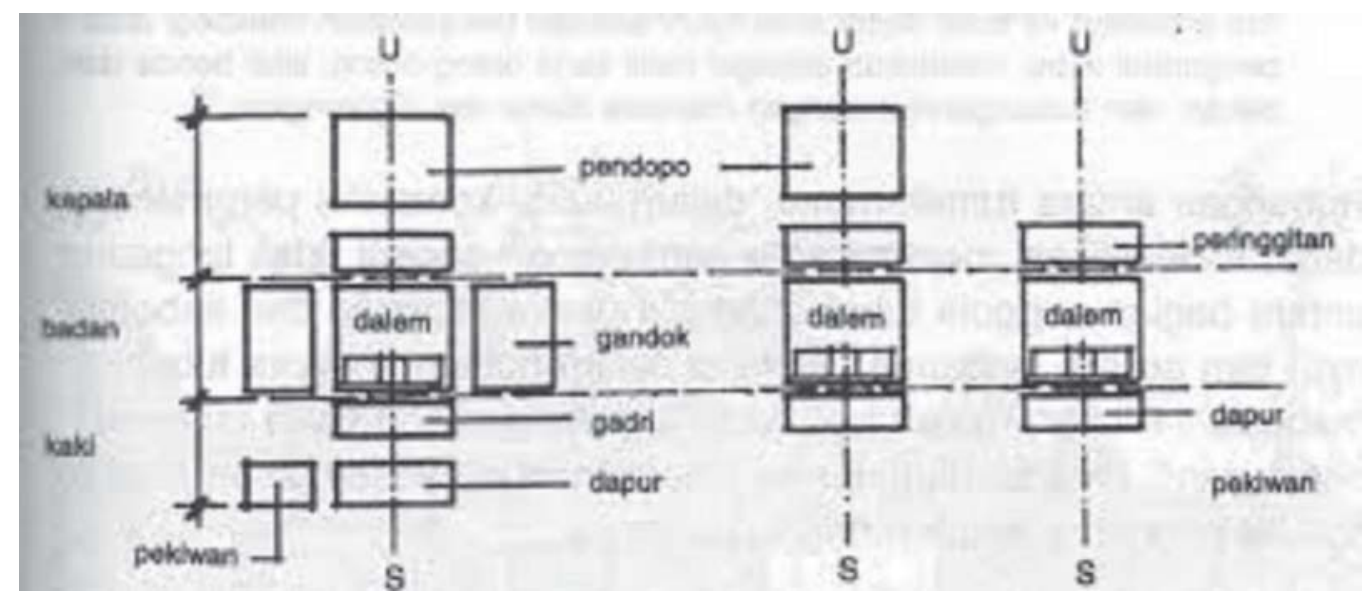

Figure 2 Housing complex consisting of several parts of the house

(Source: Heinz Frick, 1997:85)

\subsection{Benchmark for House Design}

The benchmark for the construction of a Javanese house in writing has so far originated from the Kawruh Kalang Manuscript and Kawruh Griya. According to Prijotomo (2006:106), the Kawruh Griya manuscript group contains design groups that are related to design guidelines for prospective owner of the house, while the Kawruh Kalang script group can be said to be a building construction group that contains operational steps for the undhagi / carpenters to measure and give the final appearance of construction parts Javanese house. Prijotomo (2006:173) who conducted research on 15 Javanese manuscripts summarized in the Kawruh Griya and Kawruh Kalang saying that the knowledge of the craft (house, building, architecture) of Java led to two main things, namely: dhapur griya and guna griya. Dhapur (form, figure, form) of the house consists of griya limasan, griya jugloro, griya taju, and griya kampung. While guna (function) of the house consists of griya wingking, pandhapa, paringgitan, pasanggrahan, gandhok, griya pawon, gedhogan, kandhang rajakaya, regol, bangsal pasowanan, panggenan parimatan barang, lumbung, mosque. The Javanese architectural knowledge is then complemented by the petangan (guidelines for determining the size of the Javanese building) and the angsar (character possessed by teak wood). Thus a Javanese house can be understood as a building that has a dhapur griya and guna griya and is assembled on the basis of a petangan and angsar.

\section{METHODOLOGY}

The method used in this writing is to use descriptive methods. Sampling uses a non-random sampling technique, which is a purposive sampling method (purposive sampling technique). The house sample was chosen by the criteria of houses that still had the typology of traditional Javanese houses with relatively old house age. The study took place in the dusun Cemorosewu, desa Ngancar, kecamatan Plaosan, kabupaten Magetan, with the time the research was conducted in the period of March - June 2018. 
Table 1 List of sample houses in dusun Cemorosewu

\begin{tabular}{lll}
\hline No. & \multicolumn{1}{c}{ Name of the owner } & \multicolumn{1}{c}{ Location } \\
\hline 1. & Mbah Kasmin & RT. 14 RW. 03, Dusun Cemorosewu \\
2. & Mbah Kasdi Alm (Sanem) & RT. 14 RW. 03, Dusun Cemorosewu \\
3. & Mbah Marto Kiman & RT. 14 RW. 03, Dusun Cemorosewu \\
4. & Mbah Sarju Alm & RT. 14 RW. 03, Dusun Cemorosewu \\
5. & Mbah Silam & RT. 14 RW. 03, Dusun Cemorosewu \\
\hline
\end{tabular}

Source: Field survey, 2018

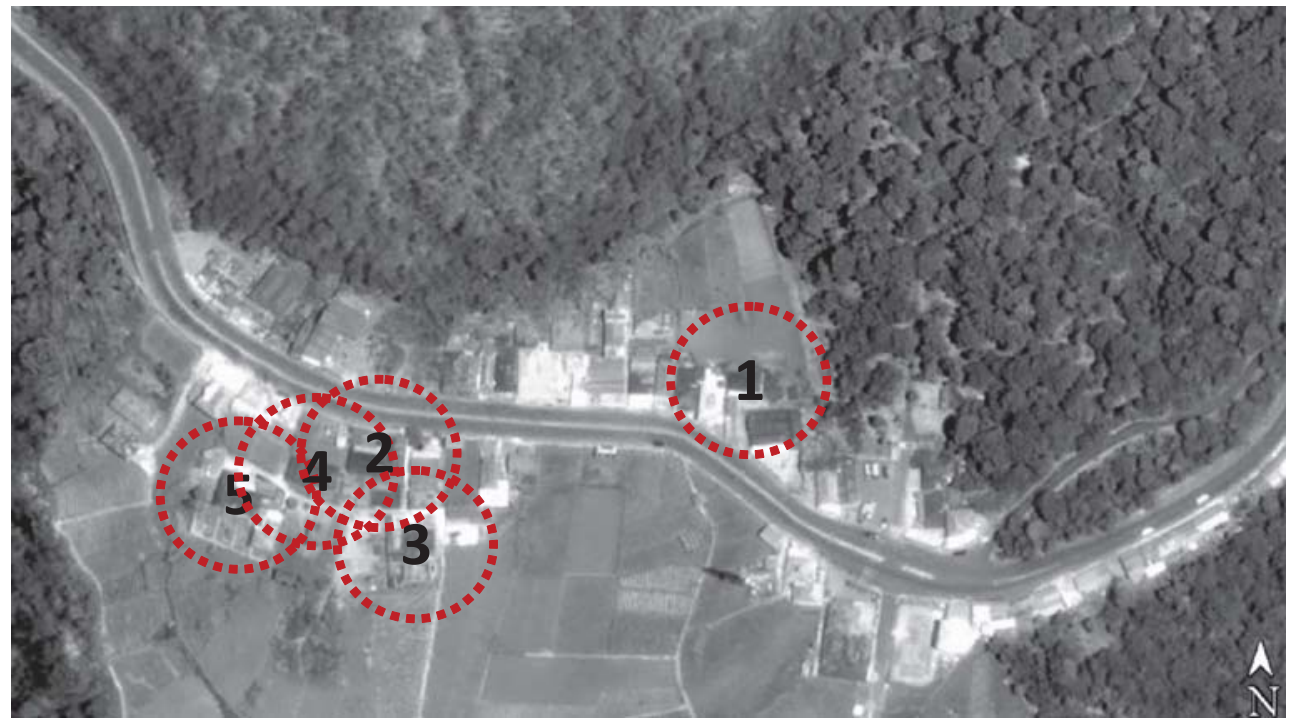

Figure 3 Map of the location of the research sample in dusun Cemorosewu (Source: Google Earth, 2018) processed

\section{RESULTS AND DISCUSSION}

Dusun Cemorosewu administratively it is one of the hamlets located on desa Ngancar, kecamatan Plaosan, kabupaten Magetan with an average land height of 1,901 meters above sea level. Located in position $7^{\circ} 39^{\prime} 51.93^{\prime \prime} \mathrm{S} 111^{\circ} 11^{\prime} 25.68^{\prime \prime} \mathrm{E}$ which borders kelurahan Sarangan to the north and to the east, dusun Ngancar to the south, and desa Gondosuli, kecamatan Tawangmangu, kabupaten Karanganyar, provinsi Jawa Tengah on the west, topographically the entire land area dusun Cemorosewu located on the mountainside with a daily average temperature of $20^{\circ} \mathrm{C}, 90 \%$ humidity and 2,116 mm of rainfall.

The forerunner history of the formation of dusun Cemorosewu is still limited to a story because there is no single text that can be used as a reference. However, according to the story of the local village elders, there were 5 people in the Dutch colonial era who were assigned by the Dutch East Indies government at that time to jogo gerdu; the term for safeguarding the border area. Upon the permission of the mandor alas (forest guards) at that time they began to settle and establish settlements in the area. The trees that grow a lot in the area are cemara or pinus trees, and like most other Javanese people to call a lot of things called sewu, the place is called Cemorosewu. 
In dusun Cemorosewu there are several natural attractions, namely the climbing gate to the top of Mount Lawu from the East Java route. Location of Wana Wisata (WW) Cemorosewu is located on plot 73/2 RPH Sarangan, BKPH Lawu Selatan, KPH Lawu DS. Cemorosewu is at an altitude of 1,820 m above sea level, located on the provincial road between Magetan - Solo via Tawangmangu. The location of WW Cemorosewu is very strategic and can be achieved both from the direction of Magetan and the direction of Solo easily with a distance of $22 \mathrm{~km}$ from Plaosan or $42 \mathrm{~km}$ from Magetan City towards Solo. The climbing route of Mount Lawu can be reached by two alternative routes, namely through Cemorosewu Gate (managed by JLPL Unit II East Java) and Cemorokandang (managed by KBM JLPL Unit I Central Java), approximately $1 \mathrm{~km}$ away.

From the observations, the traditional Javanese house in dusun Cemorosewu only has two clusters of garments, namely the griya wingking which is the limasan shaped and the griya pawon is kampung shaped, as shown in the following table.

Table 2 Floor plan and View at the sample of the house in dusun Cemorosewu

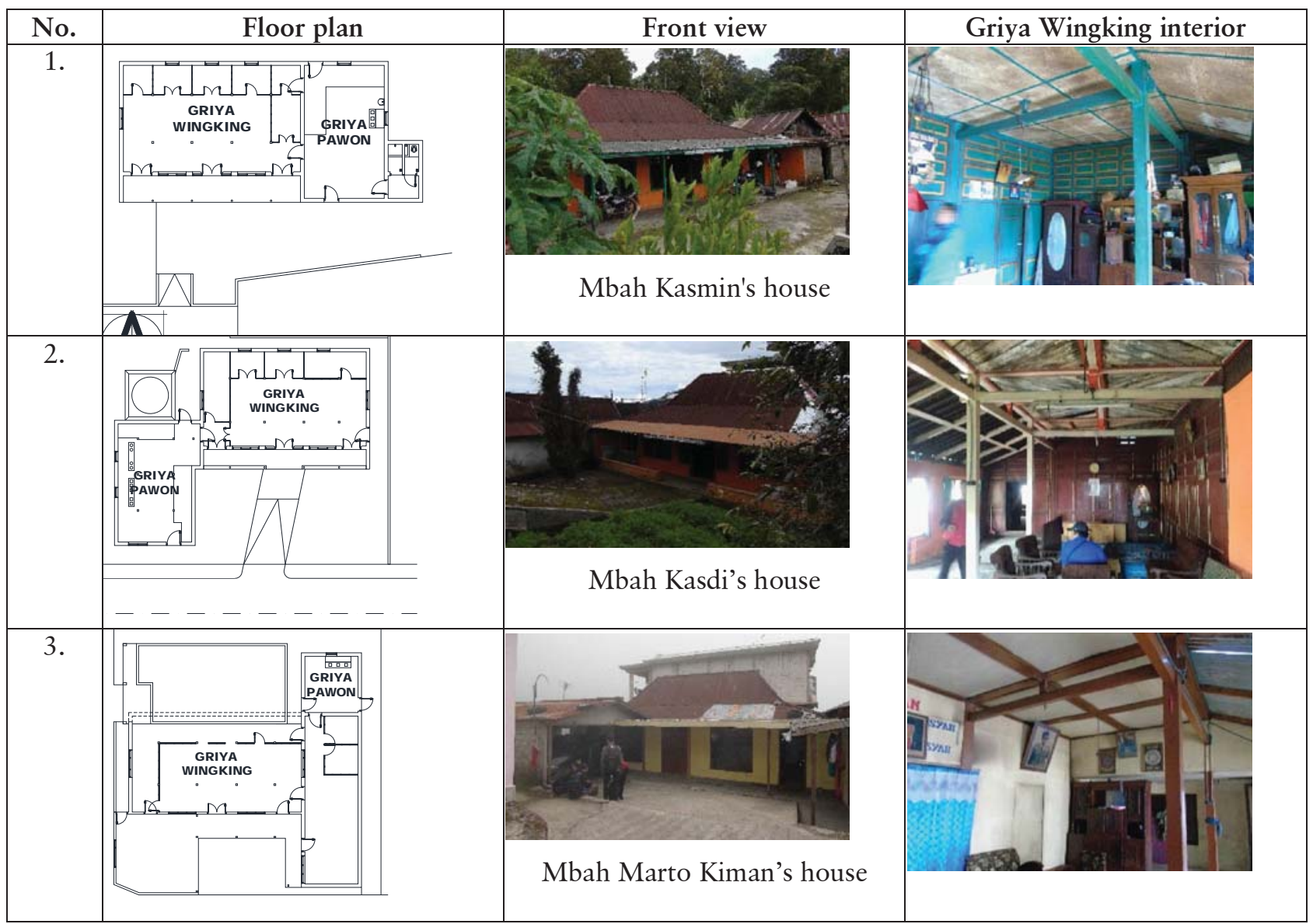




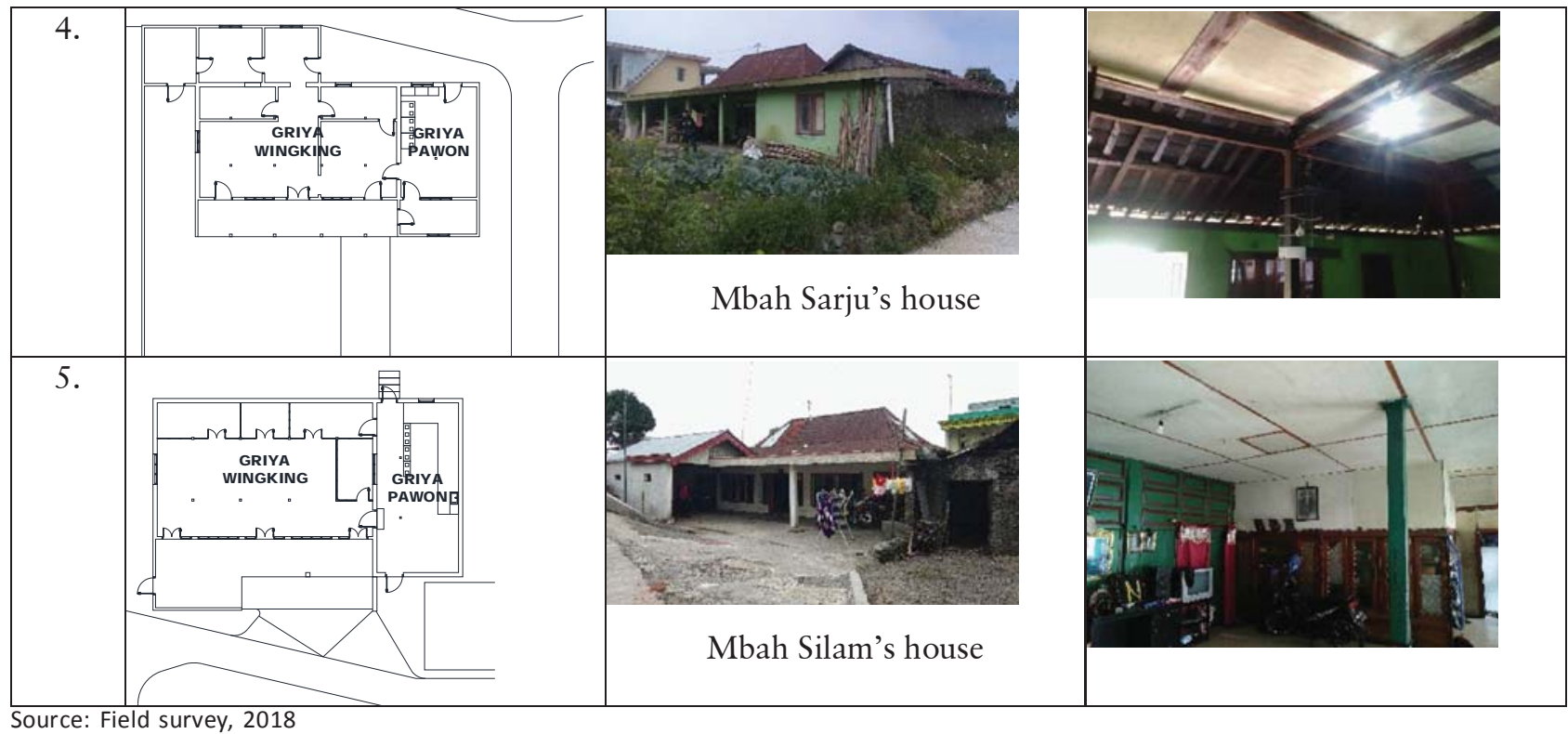

If the wingking house on the Kawruh Griya script has a high level of privacy, then this condition is different from the griya wingking in a traditional Javanese house in dusun Cemorosewu. In the spacious room in front of Senthong (by Cemorosewu residents often referred to as Ndopo) is used by the owner to carry out activities such as entertaining guests, and there are also halls for sleeping. Seeing from the room equipment with all its furniture, shows that this room is a family's residence with all its activities. From the information above, it has become one of the characteristics of the rural Javanese church in dusun Cemorosewu where one cluster of arts can be accommodated for various guna griya. Likewise with the basic floor plan, houses in dusun Cemorosewu are also different from other Javanese houses. Typically the Javanese traditional house plans are almost square where the roof is supported by 4 pillars called soko guru, but the house plans in dusun Cemorosewu are actually more parallel to the parallelogram with a roof support structure consisting of 8 pillars or soko wolu.

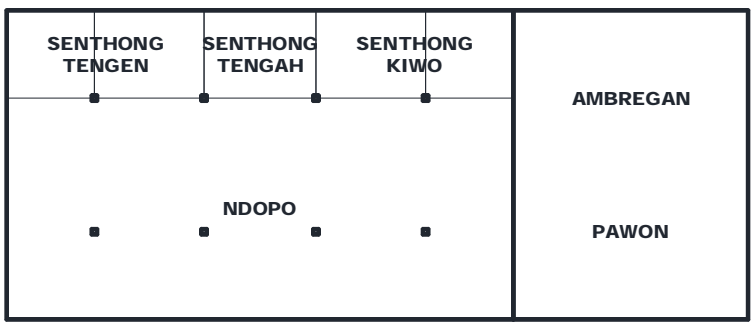

Figure 4 Chart of Guna Griya Javanese house in dusun Cemorosewu

(Source: Research Results, 2018)

In addition, like most houses in other mountainous areas traditional houses in dusun Cemorosewu also use split stone material as a wall material, and zinc / galvalum as a roof covering with wooden construction structures. Stone walls with a thickness of approximately $25 \mathrm{~cm}$ are used only for the outer walls of the house, while the inside uses a partition wall made of wood. The selection of stone and 
wood materials is easy to obtain, while the use of zinc roofs recently according to some residents said that the zinc material is more waterproof and able to ward off rainwater especially when there is rain accompanied by strong winds. Zinc material also makes the house feel warmer and able to ward off the cold mountains.

The five house samples mentioned above, except in sample 1 (Mbah Kasmin's house facing south) all houses have the same direction towards the north. This is because there is public trust in abstinence from the east, because the house facing east is believed not to bring happiness and prosperity to its inhabitants. As for the layout, the griya pawon in dusun Cemorosewu is always on the left, except for sample 2 (Mbah Kasdi's house which is on the right), or in other words that dusun Cemorosewu community uses home direction guidelines in terms of laying griya pawon.

For the circulation of activities from the griya wingking and griya pawon, there is usually one main connecting door and one additional door towards the senthong. Window placement in addition to natural lighting and air circulation, is placed on the outer wall of the pawon. There are pawon / cooking stoves with 2 or 3 holes facing west. The function of the top hole is as a place to place cooking equipment while the front hole is not only for firewood but also to warm the body. There are also more modern cooking utensils in the form of LPG gas stoves which are placed on the left side of the cooking stove and there is no permanent place.

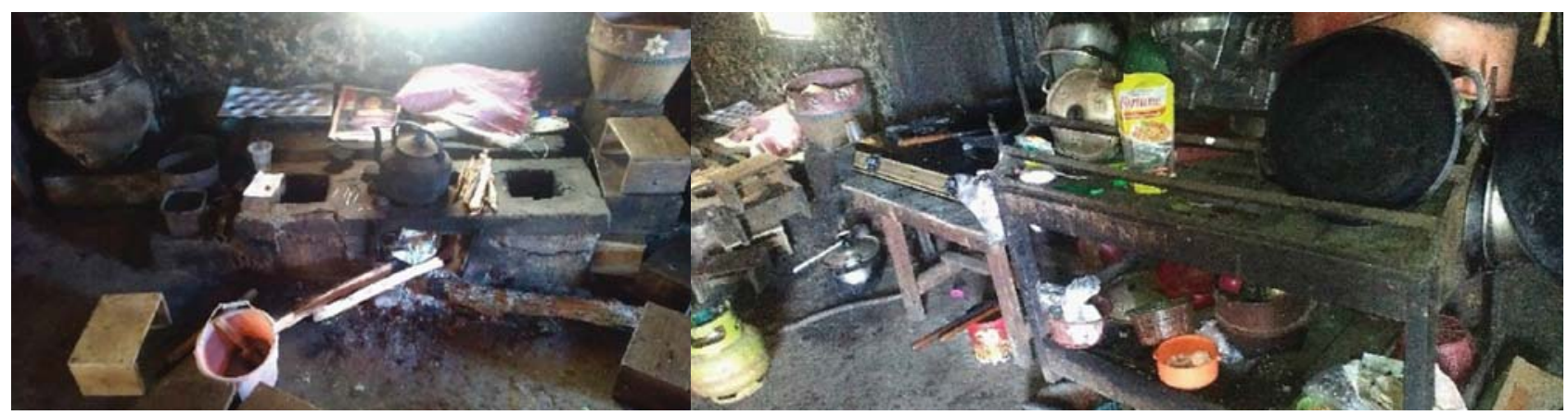

Figure 5 Pawon / firewood stove and gas stove

(Source: Research Results, 2018)

In addition to going through the window to remove smoke due to the cooking process using firewood, it has also made openings on the roof placed on top of the cooking stove / stove.

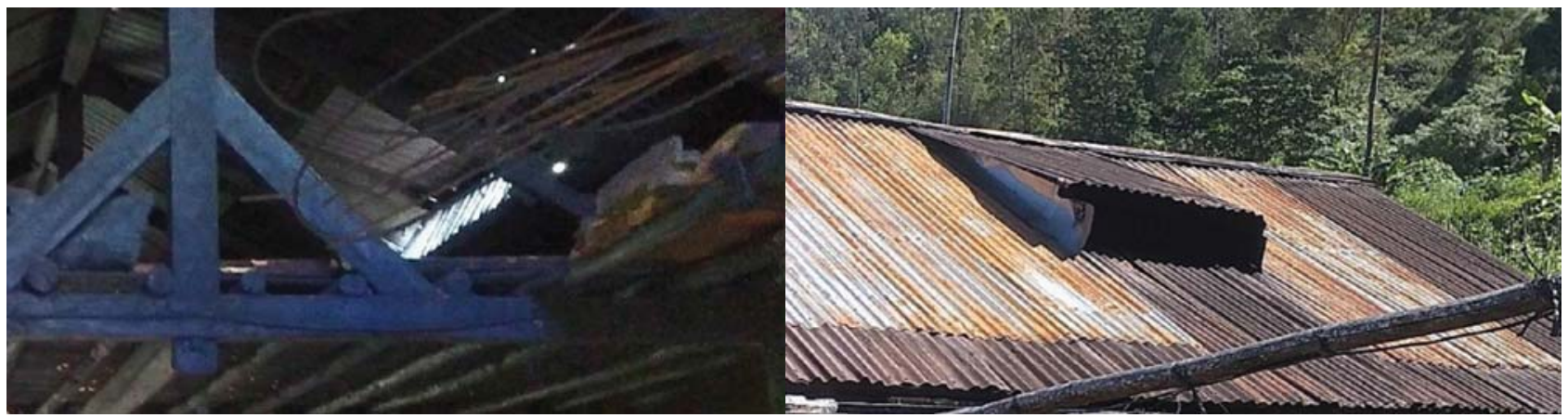

Figure 6 The roof opening as a smoke absorber in griya pawon

(Source: Research Results, 2018) 


\section{Architecture of Soko Wolu Traditional House in Dusun Cemorosewu - Magetan}

Johan Wahyudi, Respati Wikantiyoso, dan Junianto

There is a pogo placed on top of the pawon / main stove, generally functioning to store firewood or hang food so that ants or rats don't eat it, and next to it to store kitchen utensils. Also found sigirs placed on the beam of horses, made of bamboo cleavage blocks and the function of this sigiran is to store the harvest from the fields.

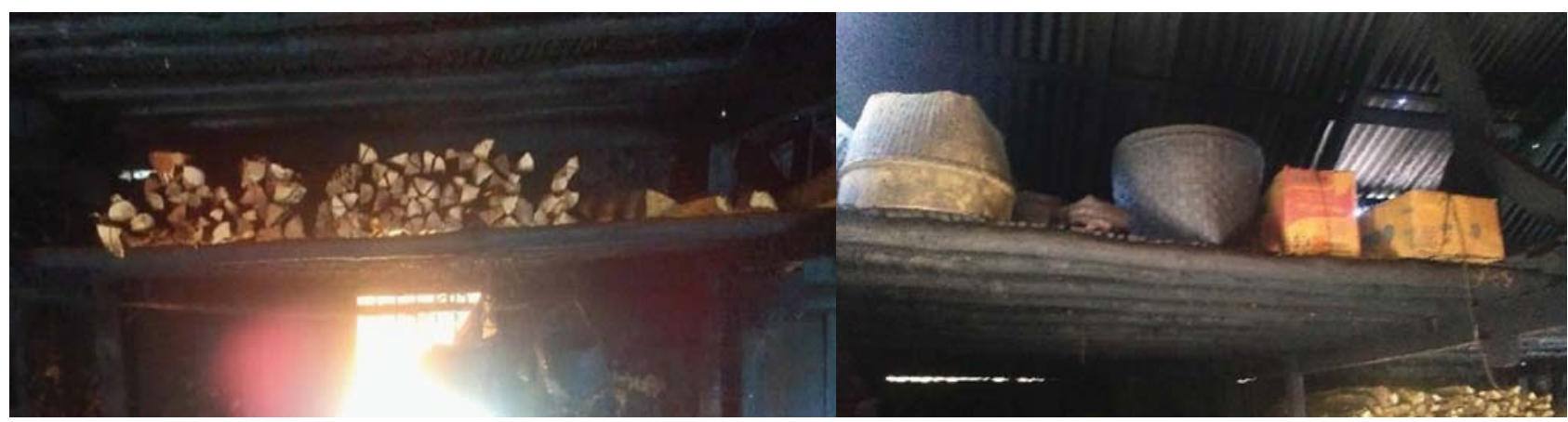

Figure 7 Pogo in one of the Cemorosewu residents' houses

(Source: Research Results, 2018)

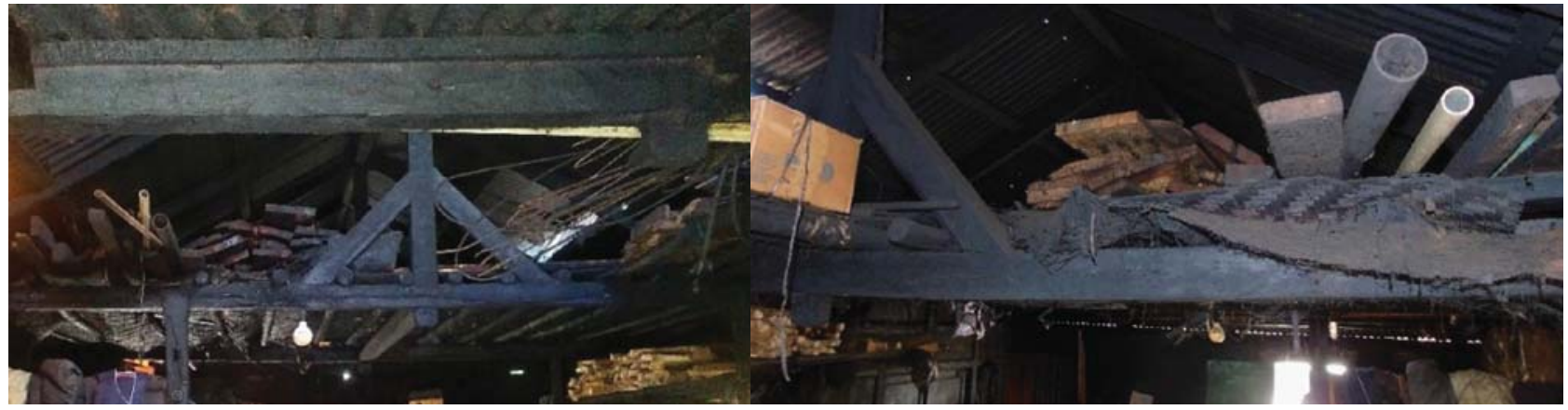

Figure 8 Sigiran in one of the Cemonosewu residents' houses

(Source: Research Results, 2018)

\section{CONCLUSION}

From the discussion of traditional Javanese house architecture in dusun Cemorosewu above, there are some conclusions as follows:

- Traditional Javanese houses in dusun Cemorosewu only have two clusters of griya, namely griya wingking with dhapur limasan and griya pawon with dhapur kampung.

- Placement of the griya pawon layout of the griya wingking is based on the direction facing the house instead of the direction of the wind, where the griya pawon is always on the left either the griya wingking faces north or south.

- $\quad$ The roof support structure of traditional Javanese houses in dusun Cemorosewu is supported by 8 (eight) poles so that they are often referred to as omah soko wolu. The walls are made of split stone with a thickness of approximately $25 \mathrm{~cm}$ and a roof covering of zinc.

- Still found cooking stoves that use fuel from firewood, along with complementary components such as pogo and sigiran and roof openings in an effort to get rid of smoke. 
LOCAL WISDOM, Vol. 10 No. 1 Januari 2018

Local Wisdom Scientific Online Journal

\section{REFERENCES}

Frick, H. (1997). Pola struktural dan teknik bangunan di Indonesia: Suatu pendekatan arsitektur Indonesia melalui pattern language secara konstruktif dengan contoh arsitektur Jawa Tengah. Yogyakarta: Penerbit Kanisius \& Soegijapranata University Press.

Hermawan. (2014). Karakteristik Rumah Tinggal Tradisional di Daerah Pegunungan Jawa Tengah. Jurnal PPKM UNSIQ III, 212-219.

Ikhsan, F. A. (2016). Arsitektur Rumah Jawa Perdesaan pada Komunitas Hindu-Jawa di Kawasan Candi Cetho Gunung Lawu. Prosiding Seminar Nasional SUSTAINABLE ARCHITECTURE AND URBANISM 2016 Universitas Diponegoro ARSITEKTUR, 101-113.

Prijotomo, J. (2006). (Re-)Konstruksi Arsitektur Jawa, Griya Jawa dalam Tradisi Tanpatulisan. Surabaya: Wastu Lanas Grafika. 